Vol. 17 (2008): 41-52.

\title{
Water baths for farmed mink: intra-individual consistency and inter-individual variation in swimming behaviour, and effects on stereotyped behaviour
}

\author{
Jaakko Mononen, Maarit Mohaibes, Sakari Savolainen and Leena Ahola \\ University of Kuopio, Department of Biosciences, PO Box 1627, FI-70211 Kuopio, Finland \\ e-mail: jaakko.mononen@uku.fi
}

\begin{abstract}
Swimming behaviour and effects of water baths on stereotyped behaviour in farmed mink (Mustela vison) were studied in three experiments. The singly-housed mink had access from their home cages to extra cages with 20.5 litre water baths. Two short-term experiments aimed to investigate how quickly adult and juvenile mink start using and how consistently they use water baths over 10 days, and whether the extent of the use correlates between dams and their females kits. A four-month experiment was designed to compare the development of stereotyped behaviour in juvenile mink housed with and without swimming opportunity. The behavioural analyses were based on several 24-hour video recordings carried out in all three experiments. There were obvious inter-individual differences and intra-individual consistency in swimming frequency and time. Farmed mink's motivation to swim can be assessed in short-term experiments, and measurement of water losses from the swimming baths and use of instantaneous sampling with 10 min sampling intervals provide quite reliable measures of the amount of swimming. The bath use of the juveniles correlated with that of their dams, indicating that an individual mink's eagerness to swim may have a genetic component. The lower amount of stereotyped behaviour in mink housed with water baths indicates that long-term access to baths may alleviate frustration in singly-housed juvenile farmed mink.
\end{abstract}

Key-words: mink, Mustela vison, fur farming, swimming, stereotyped behaviour, behavioural need, animal welfare 
Mononen, J. et al. Water baths for mink: swimming behaviour and effects on stereotypies

\section{Introduction}

Charles Darwin was challenged by his opponents with the question of how aquatic carnivores could have evolved from terrestrial carnivores (see Dunstone 1993, pp. 1-2). The opponents doubted the ability of an intermediate species to cope in either environment. Darwin used American mink (Mustela vison) as an example of a successful intermediate species. The semi-aquatic nature of mink (see also Birks 1986) and how it copes in different environments is still a controversial issue today, but in a quite different sense. Mink have been farmed for their fur since the 1860s (European Commission 2001), but farmed mink are not provided with the opportunity to swim, and it has been argued that this might be detrimental to their welfare (e.g. Nimon and Broom 1999, European Commission 2001).

Whether mink need swimming water has been investigated quite intensively in many countries recently, using various methods. Cooper and Mason (2001) discovered in a demand study that mink valued swimming water (and food) over many other resources. Other demand studies have not confirmed these findings, but it has been found that mink value swimming water and running wheels equally (as measured by the demand elasticity, Hansen and Jensen 2006). In addition, the mink used the running wheel much more than the water. Furthermore, studies comparing mink that are housed with and without water baths have not shown that baths have any long-term positive welfare effects (Skovgaard et al. 1997, Hansen and Jeppesen 2000a and b, Hansen and Jeppesen 2001a, Vinke \& Spruijt 2001, Vinke et al. 2004). On the other hand, it has been reported that if mink have water baths and then are deprived of them, they show signs of stress (Mason et al. 2001, Korhonen et al. 2003). Here it is noteworthy that many mink farms are located in areas where winter is cold (e.g. Finland and Canada), where water freezes if not warmed, which would lead to "natural deprivation" of the baths.

There is clearly not enough scientific evidence yet to support either the view that farmed mink need swimming water or the view that they do not.
Furthermore, it is highly possible that the relaxation of natural selection (e.g. Price 1999) during the domestication process of mink may have led to an increase in inter-individual differences in their attitude towards swimming water. If this is true, some mink might suffer more than others when deprived of water. It is also important to identify inter-individual differences because they cause noise in experiments and, perhaps even more importantly, may lead to discrepancies between results from different farm mink populations.

In this paper we report three experiments from a longer series of studies focusing on farmed mink's need for water baths. In the first two experiments we assessed how quickly an individual mink establishes its use of a water bath, and whether there are differences between juveniles and adults in this. Furthermore, we studied the extent of interindividual and intra-individual variation in the use of the bath in the short and long term, and the correlation in bath use between females and their progeny. Different ways of measuring the amount of swimming were also evaluated in the first and third experiment. In the third experiment we studied the short-term and long-term behavioural effects of deprivation of access to a water bath. Deprivation included "natural deprivation", i.e. the freezing of water in late autumn. We also assessed whether the deprivations affect differently mink that use baths frequently and those that use them less.

\section{Material and methods}

Three experiments were carried out in an unheated animal barn at the Research Station of the University of Kuopio, Finland. Female mink of scan-glow colour-type were used in all experiments, which were approved by the Institutional Animal Care and Use Committee of the University of Kuopio (licence number 01-34).

The mink were housed singly in standard mink cages $(85 \times 30 \times 45 \mathrm{~cm}, \mathrm{~L} \times \mathrm{W} \times \mathrm{H})$ with standard nest boxes $(27 \times 31 \times 39 \mathrm{~cm})$ with bedding. The mink housed with water baths, i.e. all mink in 
Vol. 17 (2008): 41-52.

Experiment 1 and Experiment 2 and the mink in the bath group in Experiment 3, had access to a neighbouring standard cage (without a nest box) where a 20.5-litre water bath was available. The water depth was $17 \mathrm{~cm}$. The mink in the control group in Experiment 3 had access to an empty cage of the same size. The behaviour of the mink was video-recorded with a wide-lens video-camera (Panasonic WV-BP330), a time lapse recorder (Hitachi VT-L2600E) and a Video Quad Splitter (VT-6040). The extent of bath use was analysed from the videotapes with continuous recording (Martin and Bateson 1993) in all experiments. Bath use was defined as the time the mink spent in the water (all four limbs in the water).

\section{Experiment I}

In Experiment 1, 18 naïve juvenile mink were given access to swimming water for 10 days to investigate how quickly they would start using it, how consistently they used it over the 10 days, and whether a proxy measure of swimming, i.e. the decline of water levels in the baths, could be validated.

The experimental animals had been born in May, weaned into sister-pairs at the age of eight weeks, moved to the experimental cages at the age of twelve weeks, and housed singly during the tenday experiment in August-September. The behaviour of the mink was video-recorded on days 1,2 and 10 of the experiment. The water loss from the baths over 24 hours was also measured after each 24-hour video-recording.

Intra-individual consistency in bath use between days 1, 2 and 10, and correlation between bath use and water loss from the baths were analysed with the Spearman rank-order correlation (henceforth the Spearman correlation) (Siegel and Castellan 1988). The differences in bath use between days 1 , 2 and 10 were compared with the Friedman twoway analysis of variance by ranks (henceforth the Friedman test) followed by a post hoc test. The differences between days 1,2 and 10 in the percentage of animals not swimming were compared with the Cochran Q test.

\section{Experiment 2}

In Experiment 2, two groups of adults and one group of juveniles were given ten days' access to swimming water in August. The two adult groups differed in water bath experience: the adults in one group had had prior experience with water (ten days during Experiment 1, experienced adults, $\mathrm{n}=$ 8), while the adults in the other group were naïve (naïve adults, $n=11$ ). The juveniles had no earlier water bath experience (naïve juveniles, $n=27$ ). This experiment thus allowed comparison of bath use between naïve adults and juveniles, and between experienced and naïve adults. Furthermore, since the juveniles were the offspring of the adults, their bath use could be compared with that of their dams, in order to see if individual differences in bath use might have a genetic component. Also, day-to-day (all groups) and year-to-year (experienced adults only) intra-individual consistency in bath use could be compared.

The adults had been born in May in the previous year (experienced adults) or one or two years earlier (the naïve adults), weaned at the age of eight weeks into male-female pairs, pair-housed until their first December and kept singly thereafter, except during the breeding season when they had kits. The juveniles had been born in May of the year of the experiment, weaned at the age of eight weeks into sister-pairs, moved to the experimental cages at the age of twelve weeks and housed singly through the experiment. The naïve juveniles were offspring of the adult females of both experienced and naïve adults.

The video-recordings were carried out on days 2 and 10 of the experiment. In addition to the time spent in the bath, the time spent on the edge of the bath was also recorded with continuous recording (Martin and Bateson 1993).

Intra-individual consistency in bath use from day 2 to day 10 (all groups) and from year to year (for the experienced adults only), correlation in bath use between females and their progeny (data from days 2 and 10 pooled), and correlation between swimming behaviour and staying on the edge of the bath (for the naïve juveniles only) were analysed with the Spearman correlation. There were 
Mononen, J. et al. Water baths for mink: swimming behaviour and effects on stereotypies

seven dams with one kit and ten dams with two kits in the experiment, and in the latter case the mean value for the two kits was calculated and used in analysing the correlation in swimming behaviour between the dams and their daughters to avoid pseudo-replication. The differences in bath use (time spent swimming, frequency of swimming bouts, mean swimming bout length, time spent on the edge of the bath) between the three groups were analysed with the Kruskall-Wallis one-way analysis of variance (henceforth the Kruskall-Wallis test), and the pair-wise comparisons were performed with a post hoc test described in Siegel and Castellan (1988). The differences between the two recording days were analysed with the Wilcoxon signed-ranks test (henceforth the Wilcoxon test). In addition, the number of animals not swimming at all was compared between the groups with Fisher's exact test.

\section{Experiment 3}

Experiment 3 was a longer-term study of 36 juvenile mink. Stereotypic behaviour was used to investigate whether control mink have poorer welfare than the mink in the bath group; whether artificial and natural thwarting of swimming have similar or different effects on stereotypies; and whether individual differences in bath use predict frustration when swimming is prevented.

The experimental animals had been born in May, weaned at the age of eight weeks into sister-pairs, allotted randomly to the bath group or the control group and moved to the experimental cages at the age of twelve weeks and housed singly through the experiment from August to December.

The mink in the bath group $(\mathrm{n}=18)$ were given 18 weeks of access to swimming water, broken by two periods of deprivation: an artificial one in which access was prevented experimentally for two weeks, and a natural one in which the water froze over with the arrival of winter (Table 1). The mink in the control group $(n=18)$ were housed in bath-free double-cages for 18 weeks, broken only by a twoweek period of bath access (when the bath group were artificially deprived of the baths).

Twenty-four-hour video-recordings were carried out on days 1, 2 and 10 of each of four two-week observation periods. In addition to continuous recording of the swimming behaviour, instantaneous sampling with 10 min sampling intervals (Martin and Bateson 1993) was used to record general activity (measured as the time spent outside the nest box), stereotyped behaviour and swimming behaviour.

The differences in activity and stereotyped behaviour between the two groups were analysed separately for each month with the Wilcoxon-MannWhitney test. The percentage of stereotyped behaviour between the months was compared group-wise with the Friedman test with a post hoc test described in Siegel and Castellan (1988). The relation between the frequency of stereotyped behaviour in the artificial and natural deprivation periods and bath use in the observation periods before each of the two deprivation periods were analysed with the Spearman cor-

Table 1. The schedule of Experiment 3. Study week 1 started on $12-18$ August. $\mathrm{T}_{\mathrm{a}}=$ the range of ambient temperature during the observation weeks.

\begin{tabular}{|c|c|c|c|c|}
\hline \multirow[t]{2}{*}{$\begin{array}{l}\text { Study } \\
\text { weeks }\end{array}$} & \multirow[t]{2}{*}{ Observation weeks (month) } & \multirow[t]{2}{*}{$\mathrm{T}_{\mathrm{a}}$} & \multicolumn{2}{|c|}{ Group and circumstances } \\
\hline & & & Bath & Control \\
\hline $1-5$ & 1 - 2 (Aug) & $+11-+14^{\circ} \mathrm{C}$ & Bath & No bath \\
\hline $6-7$ & $6-7$ (Sep-Oct) & $+1-+10^{\circ} \mathrm{C}$ & $\begin{array}{l}\text { No bath } \\
\text { (artificial deprivation) }\end{array}$ & Bath \\
\hline $8-16$ & $10-11(\mathrm{Oct})$ & $+0-+11^{\circ} \mathrm{C}$ & Bath & No bath \\
\hline $17-18$ & $17-18$ (Nov-Dec) & $-13-+1^{\circ} \mathrm{C}$ & $\begin{array}{l}\text { Bath frozen } \\
\text { (natural deprivation) }\end{array}$ & No bath \\
\hline
\end{tabular}


Vol. 17 (2008): 41-52.

relation. In addition to the frequency of stereotyped behaviour during the deprivation, the change in the frequency from the period preceding the deprivation to the deprivation period was also used in these analyses in order to take into account the individual baseline levels in stereotyped behaviour. The Spearman correlation was also used for analysing shortterm intra-individual consistency (i.e. consistency between observation days 1, 2 and 10 within each month) and long-term intra-individual consistency (consistency between months; data pooled from the three observations in each month) of bath use, as well as for comparing the swimming behaviour data from the continuous recording and instantaneous sampling (data from the six 24-h recordings of the bath group in August and October).

\section{Notes on statistical analyses and presen- tation of the data}

Despite transformation attempts, many variables (e.g. those related to stereotyped behaviour) never met the assumptions of parametric statistics. Therefore, statistical analyses were performed using nonparametric statistics (Siegel and Castellan 1988). Due to this non-normality of most of the variables, the results are presented not only as mean \pm standard deviation (SD), but also with median and/or minimum and maximum values. The level of statistical significance was set at the conventional 0.05 , but to facilitate readers' opportunities to do their own interpretations of the results the exact $p$-values are indicated every time the value is between 0.05 and 0.1 (whenever this is possible).

\section{Results}

\section{Experiment I}

In the juvenile mink, the number of swimming bouts was at its highest on day 2, whereas the amount of swimming time decreased and the length of the swimming bouts became shorter from days 1 and 2 to day 10 (Table 2). Water loss from the bath had also decreased by the tenth day. The number of mink that did not swim at all did not change from day to day. Twelve out of 18 mink were observed to swim on all observation days, and all animals swam at least on one observation day.

There was intra-individual consistency in the swimming time and the number of swimming bouts from day to day: the Spearman correlation coefficients $\left(r_{s}\right)$ for these variables between the days ranged from 0.70 to $0.83(p<0.001, \mathrm{n}=18)$. There was a strong correlation between the swimming time and the number of swimming bouts on days 1,2 and $10\left(r_{\mathrm{s}}=0.88-0.98, p<0.001\right)$. Water loss from the bath correlated with both the number of swimming bouts and the swimming time on all observation days $\left(\mathrm{r}_{\mathrm{s}}=0.80-0.87, p<0.001\right)$.

\section{Experiment 2}

The experienced adult mink swam the most and the naïve adult mink the least, with the naïve juveniles intermediate between these two (Table 3). These differences were clearer on the $2^{\text {nd }}$ than on the $10^{\text {th }}$ day of the experiment, since both the daily swimming time and frequency tended to increase in the naïve adults from day 2 to day 10 . The mean swimming bout length tended to be the shortest in the naïve adults, but only on day 2 . The percentage of animals that did not swim at all was highest in the naïve adult mink and lowest in the experienced adults, with the naïve juveniles intermediate between these two, but this difference did not reach statistical significance. In addition to being in the bath for an average of 5-23 $\mathrm{min} / 24$ hours, the mink spent 2-4 $\%$ of observations, corresponding to approximately $30-60 \mathrm{~min} / 24$ hours, on the edge of the bath. There was no difference in the time spent on the edge of the bath between the three groups.

Swimming behaviour between days 2 and 10 correlated in juvenile $\left(r_{s}=0.60\right.$ for the time spent swimming and $r_{\mathrm{s}}=0.63$ for swimming frequency; $p<0.01, \mathrm{n}=27$, Spearman correlation) and experienced adult mink $\left(\mathrm{r}_{\mathrm{s}}=0.83\right.$ and 0.74 , respectively; 
Mononen, J. et al. Water baths for mink: swimming behaviour and effects on stereotypies

Table 2. Swimming behaviour of juvenile mink $(n=18)$ and water loss from the baths in Experiment 1.

\begin{tabular}{|c|c|c|c|c|}
\hline & Day 1 & Day 2 & Day 10 & $p$ \\
\hline \multicolumn{5}{|l|}{ Time spent swimming $(\mathrm{min} / 24 \mathrm{~h})$} \\
\hline Mean \pm SD & $60 \pm 61^{\mathrm{A}}$ & $66 \pm 5^{\mathrm{A}}$ & $21 \pm 28^{\mathrm{B}}$ & \multirow[t]{3}{*}{$<0.01$} \\
\hline Median & 39 & 63 & 8 & \\
\hline Minimum-maximum & $0-163$ & $0-169$ & $0-82$ & \\
\hline \multicolumn{5}{|l|}{ Number of swimming bouts } \\
\hline Mean \pm SD & $101 \pm 101^{\mathrm{AC}}$ & $163 \pm 118^{\mathrm{B}}$ & $68 \pm 81^{\mathrm{AC}}$ & \multirow[t]{3}{*}{$<0.001$} \\
\hline Median & 82 & 149 & 41 & \\
\hline Minimum-maximum & $0-285$ & $0-336$ & $0-271$ & \\
\hline \multicolumn{5}{|l|}{ Mean bout length (s) } \\
\hline Mean \pm SD & $22.2 \pm 18.3^{\mathrm{a}}$ & $24.7 \pm 10.5^{\mathrm{a}}$ & $15.0 \pm 9.4^{\mathrm{b}}$ & \multirow[t]{3}{*}{$<0.05$} \\
\hline Median & 29.8 & 25.7 & 15.4 & \\
\hline Minimum-maximum & $0-44.4$ & $0-45.9$ & $0-33.0$ & \\
\hline Number (and \%) of animals not swimming & $4 / 18(22 \%)$ & $1 / 18(6 \%)$ & $2 / 18(11 \%)$ & $\mathrm{NS}^{\mathrm{x}}$ \\
\hline \multicolumn{5}{|l|}{ Water loss from the bath (l) } \\
\hline Mean \pm SD & $9.7 \pm 4.7^{\mathrm{a}}$ & $10.6 \pm 4.6^{\mathrm{a}}$ & $7.2 \pm 5.7^{\mathrm{b}}$ & \multirow[t]{2}{*}{$<0.05$} \\
\hline Median & 9.8 & 12.0 & 5.7 & \\
\hline
\end{tabular}

Table 3. Bath-related behaviour of mink in Experiment 2. Mean $\pm \mathrm{SD}$ (median; minimum-maximum) or number (and percentage) of animals.

\begin{tabular}{|c|c|c|c|c|}
\hline & $\begin{array}{l}\text { Naïve juveniles } \\
(\mathrm{n}=27)\end{array}$ & $\begin{array}{l}\text { Naïve adults } \\
(\mathrm{n}=11)\end{array}$ & $\begin{array}{l}\text { Experienced } \\
\text { adults }(\mathrm{n}=8)\end{array}$ & $p_{1}$ \\
\hline \multicolumn{5}{|c|}{ Time spent swimming $(\min / 24 h)$} \\
\hline Day 2 & $\begin{array}{l}6.2 \pm 8.0^{\mathrm{ab}} \\
(3.4 ; 0-25.8)\end{array}$ & $\begin{array}{l}1.4 \pm 2.1^{\mathrm{a}} \\
(1.0 ; 0-5)\end{array}$ & $\begin{array}{l}23.3 \pm 24.8^{b} \\
(12.4 ; 1.2-60.6)\end{array}$ & $<0.05$ \\
\hline Day 10 & $\begin{array}{l}6.5 \pm 11.6 \\
(3.5 ; 0-57.6)\end{array}$ & $\begin{array}{l}4.8 \pm 6.0 \\
(2.8 ; 0-16.5)\end{array}$ & $\begin{array}{l}18.5 \pm 22.4 \\
(9.4 ; 0.2-54.3)\end{array}$ & NS \\
\hline $\begin{array}{l}p_{2} \\
\text { Number of swim }\end{array}$ & NS & $=0.06$ & NS & \\
\hline Day 2 & $\begin{array}{l}12 \pm 15^{\mathrm{a}} \\
(8 ; 0-53)\end{array}$ & $\begin{array}{l}5 \pm 7^{\mathrm{a}} \\
(1 ; 0-18)\end{array}$ & $\begin{array}{l}83 \pm 94^{b} \\
(24 ; 7-220)\end{array}$ & $<0.01$ \\
\hline Day 10 & $\begin{array}{l}17 \pm 26 \\
(8 ; 0-105)\end{array}$ & $\begin{array}{l}19 \pm 22 \\
(12 ; 0-63)\end{array}$ & $\begin{array}{l}77 \pm 83 \\
(48 ; 1-196)\end{array}$ & NS \\
\hline $\begin{array}{l}p_{2} \\
\text { Mean bout length }\end{array}$ & NS & $=0.05$ & $\mathrm{NS}$ & \\
\hline Day 2 & $23 \pm 21$ & $8 \pm 12$ & $21 \pm 14$ & $=0.07$ \\
\hline Day 10 & $19 \pm 16$ & $9 \pm 9$ & $13 \pm 5$ & NS \\
\hline $\begin{array}{l}p_{2} \\
\text { On the edge of th } \\
\text { (\% of observation }\end{array}$ & NS & NS & NS & \\
\hline Day 2 & $\begin{array}{l}4 \pm 2 \\
(3 ; 0.7-9.7)\end{array}$ & $\begin{array}{l}4 \pm 4 \\
(3 ; 0-11.0)\end{array}$ & $\begin{array}{l}3 \pm 2 \\
(4 ; 0.7-5.5)\end{array}$ & NS \\
\hline Day 10 & $\begin{array}{l}4 \pm 3 \\
(4 ; 0-14)\end{array}$ & $\begin{array}{l}2 \pm 3 \\
(0.7,0-9)\end{array}$ & $\begin{array}{l}3 \pm 2 \\
(2.1 ; 0.7-7)\end{array}$ & NS \\
\hline $\begin{array}{l}p_{2} \\
\text { Number (and \%) } \\
\text { not swimming }\end{array}$ & NS & NS & NS & \\
\hline Day 2 & $7(26 \%)$ & $5(45 \%)$ & $0(0 \%)$ & $=0.09$ \\
\hline Day 10 & $4(15 \%)$ & $3(27 \%)$ & $0(0 \%)$ & NS \\
\hline Days 2 and 10 & $3(11 \%)$ & $2(18 \%)$ & $0(0 \%)$ & NS \\
\hline
\end{tabular}

$p_{1}$ : The Kruskall-Wallis one-way analysis of variance by ranks or Fisher's exact test between the groups; ${ }^{\text {ab }}=$ values without a common letter differ from each other at the level of $p<0.05$

$p_{2}$ : The Wilcoxon signed-ranks test between days 2 and 10 within the groups

NS: $p>0.1$ 
Vol. 17 (2008): 41-52.

$p<0.05, \mathrm{n}=8)$ but not in naïve adults $\left(\mathrm{r}_{\mathrm{s}}=0.30\right.$ and 0.22 , respectively; $p>0.1, \mathrm{n}=11$ ). There was a moderate correlation between the two years in the frequency of swimming bouts in the experienced adults, but the correlation for time spent swimming between the years was not statistically significant (Fig. 1). There was a moderate correlation in the time spent swimming between the dams and their daughters (Fig. 2).

\section{Experiment 3}

In the bath group, the time spent in the bath decreased from August (mean \pm SD $1.1 \pm 1.1 \%$ of time, range 0-52 $\mathrm{min} / 24 \mathrm{~h}$; data pooled from days 1,2 and 10 of a two-week period ) to October $(0.1 \pm 0.2 \%$, $0-10 \mathrm{~min}$ ), and the baths were used the most in November-December (4.8 $\pm 2.1 \%, 38-162 \mathrm{~min})$, when they were frozen (the Friedman test: $p<0.05$ for all three pair-wise comparisons in a post hoc test, $\mathrm{n}=17$ ). The time spent in the bath correlated between days 1,2 and 10 within the two-week observation periods in August and October $(0.48<$ $\mathrm{r}_{\mathrm{s}}<0.66,0.06>p>0.003$, Spearman correlation, $\mathrm{n}=17-18)$ whereas the correlation was weaker in November-December $\left(0.29<\mathrm{r}_{\mathrm{s}}<0.52,0.26>p>\right.$ $0.03, \mathrm{n}=17-18$ ). The time spent in the bath (data from days 1,2 and 10 pooled within each month) correlated between August and October $\left(\mathrm{r}_{\mathrm{s}}=0.58, p\right.$ $<0.05, \mathrm{n}=17)$, tended to correlate between October and November-December $\left(\mathrm{r}_{\mathrm{s}}=0.47, p=0.06, \mathrm{n}\right.$ $=17)$, and did not correlate between August and November-December $\left(\mathrm{r}_{\mathrm{s}}=0.18, p>0.1, \mathrm{n}=17\right)$. The control group spent $0.2 \pm 0.3 \%(0-15 \mathrm{~min})$ of their time in the bath in September-October, i.e. in the only two week period that they had baths available.

The mink in the bath group showed less stereotyped behaviour than the control mink, except during the artificial deprivation period (when the bath group did not have the baths and the control group did) (Fig. 3: top). The control animals were more active (outside the nest box) than those with the bath in August and October (Fig. 3: bottom). The situation was reversed for activity in the artificial deprivation period, i.e.

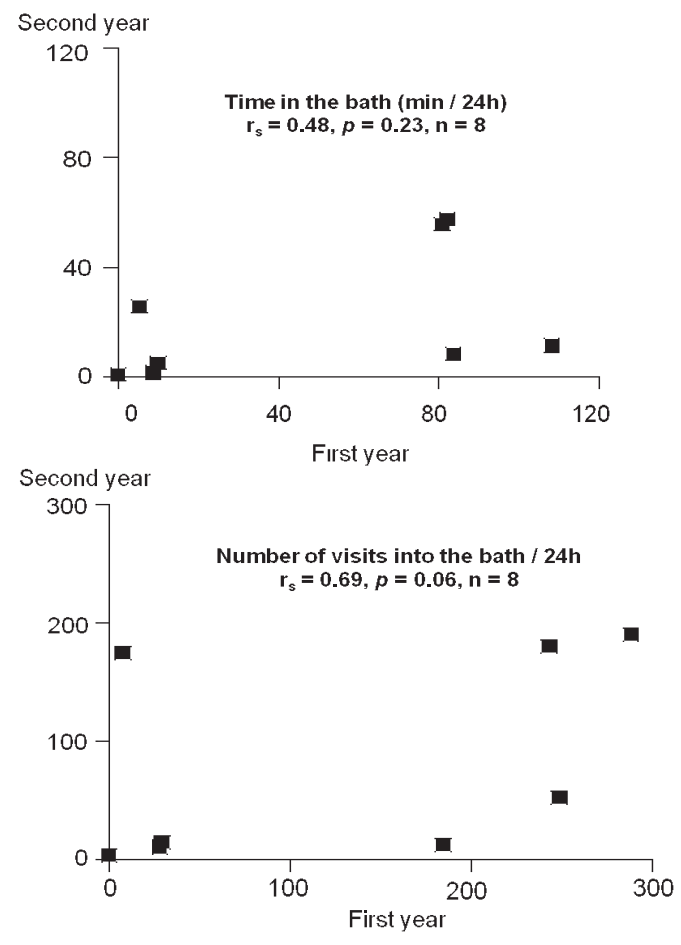

Fig. 1. Correlation in the frequency of swimming bouts (top) and the time spent in the water bath (bottom) between two consecutive years in eight female mink (experienced females). The data are based on the mean of two 24-hour recordings per year. $\mathrm{r}_{\mathrm{s}}=$ Spearman correlation coefficient.

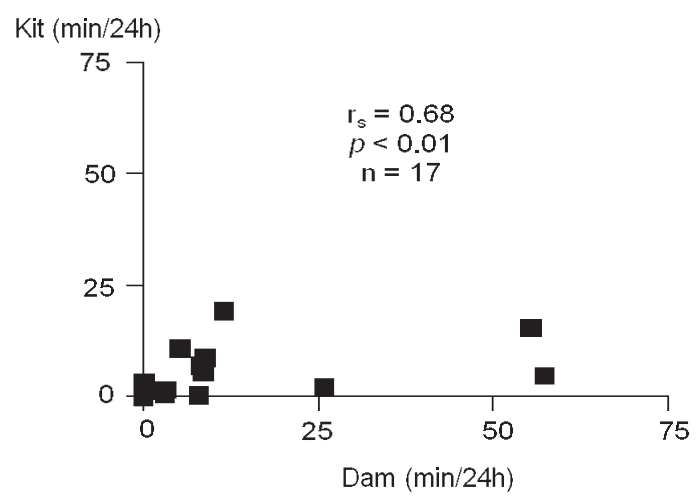

Fig. 2. Correlation in the time spent in the water pool between mink dams and their female kits. The data are based on the average time spent in the water bath during two 24-hour recordings. $r_{s}=$ Spearman correlation coefficient. 
Mononen, J. et al. Water baths for mink: swimming behaviour and effects on stereotypies

when the bath group did not have the baths and the control group did. There was no difference in activity between the groups in November-December when the baths were frozen.

The Friedman test revealed differences $(p<0.001)$ between the months in the percentage of stereotyped behaviour in both groups (Figure 3: top). The pair-wise post hoc comparisons for the bath group showed increases only from August to NovemberDecember, whereas in the control group increases were found from August to November-December,

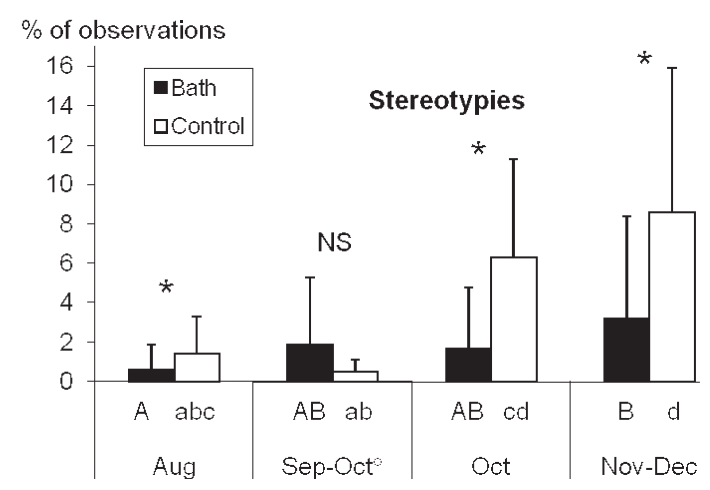

$\%$ of observations

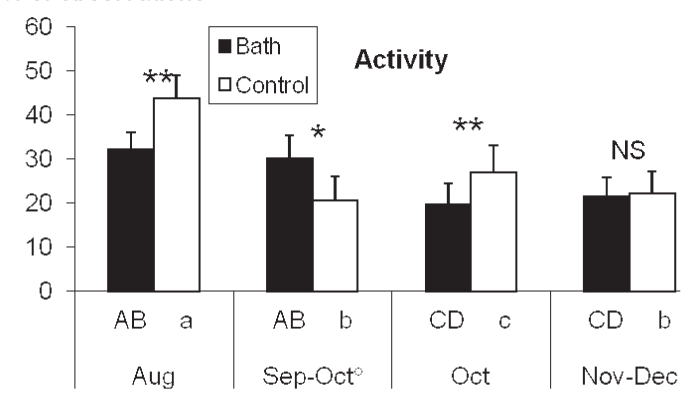

Fig. 3. Stereotyped behaviour and activity ( $\%$ of observations, mean \pm SD) in juvenile mink housed with and without water baths. ${ }^{\circ}$ In September-October the bath group did not have and the control group had the baths for a twoweek period. $* p<0.05$, ** $p<0.01$, NS $p>0.1$ : difference between the groups within an observation period (Wilcoxon-Mann-Whitney test). Letters below the columns indicate differences $(p<0.05)$ between the observation periods within a group (upper case = bath group, lower case $=$ control group): columns without a common letter differ from each other (Friedman test with a post hoc test). from September-October to October, and from September-October to November-December.

The bath group mink which swam more in August and October, i.e. the observation periods before the deprivations, did not show more stereotyped behaviour than the less active bath users during the artificial or natural deprivation: $\mathrm{r}_{\mathrm{s}}=0.12(p=0.65$, $\mathrm{n}=18$, Spearman correlation $)$ and $\mathrm{r}_{\mathrm{s}}=0.11(p=$ $0.69, \mathrm{n}=17)$, respectively. Neither did the changes in the percentage of stereotypies from the observation period preceding the deprivation period to the deprivation period correlate with swimming time in August $\left(\mathrm{r}_{\mathrm{s}}=0.09, p=0.73, \mathrm{n}=18\right)$ or October $\left(\mathrm{r}_{\mathrm{s}}=0.07, p=0.79, \mathrm{n}=17\right)$.

The two recording methods for the amount of swimming, continuous recording and instantaneous sampling, produced more similar results in August (when swimming was more frequent) than in October (when swimming was less frequent): the Spearman correlation coefficients $\left(\mathrm{r}_{\mathrm{s}}\right)$ between the two recording rules were $0.95(p<0.001), 0.84(p$ $<0.001)$ and $0.60(p<0.01)$ in August $(\mathrm{n}=18)$, and $0.36(p>0.1), 0.34(p>0.1)$ and $0.73(p<$ $0.001)$ in October $(\mathrm{n}=17-18)$ for observation days 1,2 and 10 , respectively.

\section{Discussion}

In the present three experiments the mean lengths of swimming bouts varied from a few to tens of seconds, which is in accordance with earlier studies in farmed mink (de Jonge and Leipoldt 1994 cited in Vinke 2004, Hansen and Jeppesen 2001b), and the behaviour of mink in the wild (Birks 1986, Dunstone 1993). Mink naïve in regard to the water baths established their swimming in a few days, especially in the case of juvenile animals. The intra-individual consistency in swimming behaviour was obvious from day to day, week to week, month to month and year to year. The fast establishment together with the consistency in bath use implies that an individual mink's motivation to swim can be assessed in fairly short-term experiments. (By motivation to swim we mean the internal process 
Vol. 17 (2008): 41-52.

that underlies swimming behaviour and that is reflected by a mink's tendency, or 'eagerness', to show swimming behaviour [cf. Toates 2002]: i.e. the frequency of swimming bouts and the total time spent in a water bath are interpreted to be measures of motivation.)

The daily time spent in the bath had a high correlation with the frequency of swimming bouts and water loss from the baths. The results indicate that the amount of swimming can be evaluated quite easily by measuring these parameters. The use of water loss as a measure of the amount of swimming behaviour in mink has also been reported earlier (Hansen and Jeppesen 2001b, Korhonen and Niemelä 2002, Korhonen et al. 2003). The underlying mechanism, i.e. the fairly constant amount of water carried away from the bath after each swimming bout, has been described in detail in Korhonen and Niemelä (2002). Compared with the more laborious continuous recording, instantaneous sampling with 10 min sampling intervals also provides a fairly reliable estimation of the amount of swimming (provided that the mink use the baths for at least tens of minutes per day).

It has been strongly argued that swimming is essential for the welfare of farmed mink (Nimon and Broom 1999, European Commission 2001). This argument has been justified with reference to the behaviour of mink in the wild. The wild mink has been characterised as a semiaquatic animal (Dunstone 1993), and we have not found any reports that mink in the wild thrive if totally terrestrial, although increased competition for aquatic prey may make mink "more terrestrial" (Bonesi et al. 2006). Thus, it can be supposed that motivation to swim is deeply rooted in mink's genes, and indeed, we found a moderate correlation in swimming behaviour between dams and their kits. However, although age and experience did not affect mink's first hand interest in water baths, i.e. tendencies to stand at the edge of the bath, they did affect the actual immersion in the bath. Naïve adults were slower to start swimming than naïve juveniles, but by the end of the ten days both groups swam to a rather similar extent. These results indicate that despite the putative genetic component, experience also plays a role in an individual mink's motivation to swim.

The inter-individual variation in swimming was remarkably large in the present study, as has been observed in earlier studies (Hansen and Jeppesen 2001b, Korhonen et al. 2003). It is also worth emphasising that earlier reports (e.g. Korhonen et al. 2003) as well as our present results show that some farmed mink make little or no use of water baths. Accordingly, the data from the wild support the view that swimming fulfils an important feature of a behavioural need in the mink, i.e. all individuals of the species perform the behaviour frequently and regularly or seek for water as a key stimulus to release swimming and/or foraging behaviour (Stolba and Wood-Gush 1984, Vinke 2004), but data from farmed mink and findings in the wild are to some extent contradictory.

There is a consensus that the domestication process does not delete behaviours but rather affects the threshold to perform various behavioural patterns (Price 1999, Jensen 2002 pp. 27-29). Increased inter-individual variation in the strength of the motivation to perform a behavioural pattern may be due to the relaxation of natural selection during domestication (e.g. Price 1999). This could explain the large inter-individual variation in the swimming motivation of mink: swimming has not been essential for survival during the approximately 80-generation-long (European Commission 2001) domestication process of farmed mink kept in cages mostly without a swimming opportunity. It can, then, be hypothesised that farmed mink with a stronger motivation to swim would be more frustrated when deprived of the opportunity to swim than mink with a weaker motivation to swim, and show more stereotyped behaviour due to this frustration (see e.g. Fraser and Broom 1990, Mason and Latham 2004). However, in our small-scale study we found no indication that the mink which swam more had more stereotyped behaviours when they were deprived of baths than those that swam less.

Instead, we found that the juvenile mink housed with swimming baths had less stereotypies than those housed without baths, indicating that the baths may have alleviated frustration. This result is 


\section{Mononen, J. et al. Water baths for mink: swimming behaviour and effects on stereotypies}

in conflict with those of earlier studies (Skovgaard et al. 1997, Hansen and Jeppesen 2000b, Korhonen et al. 2003), which may be due to differences in the age of the experimental animals and the methods used to analyse behaviour. We provided baths to juvenile animals, who may not yet have established stereotyped behaviour (cf. Mason 1993), whereas many other studies have been carried out with adults (Warburton and Mason 2003, Korhonen et al. 2003, Hansen and Jensen 2006). Developing stereotypies are easier to attenuate by enriching the housing environment than already established stereotypies (Mason and Latham 2004). The difference in stereotypies between the experimental and control groups was observed already in August during the first two weeks after providing the bath group with the swimming opportunity. Furthermore, in the control group the otherwise steady increase in the frequency of stereotypies in the course of the autumn was interrupted by the two week period in September-October when they had the baths. These findings support the conclusion that stereotypies were not firmly established during our study with juvenile animals.

We also measured stereotypies on a 24-hour basis, whereas in most other studies behavioural observations have been limited to day-time (Skovgaard et al. 1997, Hansen and Jeppesen 2000b). Farmed mink are most prone to perform stereotyped behaviour before and after feeding (Mason 1993), and they are fed during the day-time. Therefore, it can be assumed that most mink may perform stereotypies during the day-time, and only 24-hour observations can reveal the true differences in the occurrence of stereotypies between experimental groups in $M$. vison, which is active also at night (wild animals, Birks 1996; farmed animals, Hansen et al. 1994).

It is important to emphasise that the baths certainly had enrichment value for the mink. In addition to swimming, the mink spent a lot of time on the edge of the baths, which has also been observed earlier in farmed mink (Korhonen et al. 2003). This behaviour corresponds well with that of mink in the wild: they stare into the water before diving to catch their prey (Dunstone 1993). The mink were also particularly interested in the baths when they were frozen in November-December. The use of the frozen bath tended to correlate with swimming time earlier in the autumn, indicating that the interest in the baths was sustained even though its properties changed radically. The difference in the amount of stereotypies between mink housed with a bath and those without was also greatest in November-December, which may either indicate that the frustration-alleviating effects of the baths were greatest then or simply result from the difference between the groups in the rate at which stereotypies developed in the course of the autumn.

On the other hand, we cannot be absolutely sure that the higher number of stereotypies in the control group in Experiment 3 was due to the lack of swimming opportunity per se. It is possible that the frustration resulted from seeing or hearing the bath group mink swimming (cf. Vinke 2004). The two groups in the present study were in cage rows on two sides of a $100 \mathrm{~cm}$ wide corridor in the experimental animal barn. The view from the cages in one row to the cages in the opposite row was not totally obstructed by the two nest box rows between the cages, and a mink looking over its nest box might be able to see parts of the swimming pools in the opposite cage row. However, being able to see water may have little effect on mink's motivation to work for access to water baths (Warburton and Mason 2003).

\section{Conclusions}

There were very large inter-individual differences in the frequency of swimming bouts and time spent swimming in farmed mink, but due to the intraindividual consistency in swimming behaviour, farmed mink's swimming behaviour can be assessed in short-term experiments, especially in juvenile animals. Furthermore, measuring water losses from the swimming baths and instantaneous sampling with a 10 min sampling interval proved to be less laborious than continuous recording, while still providing quite reliable measures of the amount of swimming behaviour. 
Vol. 17 (2008): 41-52.

The bath use of the juveniles correlated with that of their dams, which may indicate that an individual mink's eagerness to swim has a genetic component.

A long-term experiment showed that mink housed without a water bath displayed more stereotypic behaviour than mink housed with a bath. This suggests that water baths might have positive effects on the welfare of singly-housed mink. However, preventing access to water baths experimentally or naturally via freezing did not increase stereotypic behaviour statistically significantly. Furthermore, individual differences in the amount of swimming did not predict individual differences in stereotypic behaviour during thwarting.

Acknowledgements. The study was carried out at the Research Station of the University of Kuopio (Juankoski, Finland). We are grateful to the staff of the research station for taking care of the animals and helping in carrying out the experiments. We thank the two anonymous referees for their constructive comments on this paper. This study was supported by the Fur Animal Welfare Research Committee and the Emil Aaltonen Fund.

\section{References}

Birks, J.D.S. 1986. Mink. Oswestry, UK: Anthony Nelson. $24 \mathrm{p}$.

Bonesi, L., Strachan, R. \& Macdonald, D.W. 2006. Why are there fewer signs of mink in England? Considering multiple hypotheses. Biological Conservation 130: 268-277.

Cooper, J.J. \& Mason, G.J. 2001. The use of operant technology to measure behavioural priorities in captive animals. Behaviour Research Methods, Instruments and Computers 33: 427-434.

Dunstone, N.1993. The mink. London, UK: T and AD Poyser. $232 \mathrm{p}$.

European Commission 2001. The welfare of animals kept for fur production. Report of the Scientific Committee on Animal Health and Animal Welfare. Adopted on 12-13 December 2001. 211 p.

Fraser, A.F. \& Broom, D.M. 1990. Farm animal behaviour and welfare. 3rd ed. London, UK: Baillière Tindall. 437 p.

Hansen, C.P.B. \& Jeppesen, L.L. 2000a. Short term behavioural consequences of denied access to environmental facilities in mink. Agricultural and Food Science in Finland 9: 149-155.

Hansen, C.P.B. \& Jeppesen, L.L. 2000b. Effects of blocking farm mink's feed access with open water. Agricultural and Food Science in Finland 9: 157-163.
Hansen, C.P.B. \& Jeppesen, L.L. 2001a. Swimming activity of farm mink (Mustela vison) and its relation to stereotypies. Acta Agriculturæ Scandinavica, Section A, Animal Science 51:71-76.

Hansen, C.P.B. \& Jeppesen, L.L. 2001b. Use of water for swimming and its relationship to temperature and other factors in farm mink (Mustela vison). Acta Agriculturæ Scandinavica, Section A, Animal Science 51: 89-93.

Hansen, S.W. \& Jensen, M.B. 2006. Quantitative evaluation of the motivation to access a running wheel or a water bath in farm mink. Applied Animal Behaviour Science 98: 127-144.

Hansen, S.W, Hansen, B.K \& Berg, P. 1994. The effects of cage environment and ad libitum feeding on the circadian rhythm, beavhiour and feed intake of farm mink. Acta Agriculturæ Scandinavica, Section A, Animal Science 44: 120-127.

Jensen, P. 2002. Behavioural genetics, evolution and domestication. In: Jensen, P. (ed.), The ethology of domestic animals. An introductory text. Wallingford, UK: CABI Publishing. p. 13-30.

Jonge, G. de \& Leipoldt A.L. 1994. Grote verrijkte kooien, zwemwater en onrustig gedrag van nertsen. De Pelsdierenhouder 44: 137-143. [Large enriched cages, swimming water and restless behaviour in mink]

Korhonen, H.T. \& Niemelä, P. 2002. Water absorption and the drying and cooling rates in mink (Mustela vison) following simulated diving. Animal Science 74: 277-283.

Korhonen, H.T., Jauhiainen, L. \& Niemelä, P. 2003. Effect of swimming deprivation on adrenocortical and behavioural responses in farmed mink (Mustela vison). Annuals of Animal Science 3: 145-163.

Martin, P. \& Bateson, P. 1993. Measuring behaviour. An introductory guide. Cambridge, UK: Cambridge University Press. 222 p.

Mason, G.J. 1993. Age and context affect the stereotypies of caged mink. Behaviour 127: 191-229.

Mason, G.J., Cooper, J. \& Clarebrough, C. 2001. Frustrations of fur-farmed mink. Nature 410: 35-36.

Mason, G.J. \& Latham, N.R. 2004. Can't stop, won't stop: is stereotypy a reliable animal welfare indicator? Animal Welfare 13: 57-69.

Nimon, A.J. \& Broom, D.M. 1999. The welfare of farmed mink (Mustela vison) in relation to housing and management: a review. Animal Welfare 8: 205-228.

Price, E.O. 1999. Behavioral development in animals undergoing domestication. Applied Animal Behaviour Science 65: 245-271.

Siegel, S. \& Castellan N.J. 1988. Nonparametric statistics for the behavioural sciences. 2nd ed. New York, USA: McGraw-Hill. 399 p.

Skovgaard, K., Jeppesen L.L. \& Hansen, C.P.B. 1997. The effect of swimming water and cage size on the behaviour of ranch mink (Mustela vison). Scientifur 21: 253-259.

Stolba, A. \& Wood-Gush, D. 1984. The identification of behavioural key features and their incorporation into a housing design for pigs. Annales de Recherches Véterinaires 15: 287-298.

Toates, F. 2002. Physiology, motivation and the organization of behaviour. In: Jensen, P. (ed.), The ethology of domestic animals. An introductory text. Wallingford, UK: CABI Publishing. p. 31-50.

Vinke, C.M. 2004. Cage enrichments and the welfare of 
Mononen, J. et al. Water baths for mink: swimming behaviour and effects on stereotypies

farmed mink. PhD Thesis, Utrecht University. Universal Press, Veenendaal, The Netherlands.

Vinke, C.M. \& Spruijt, B.M. 2001. Swimming water for farmed mink: essential of not? In: Garner, J.P., Mench, J.A. \& Heekin, S.P. (eds.). Proceedings of the 35th International Congress of the International Society for Applied Ethology. 4-9 August, California, Davis.
Vinke, C.M. van den Bos, R. \& Spruijt, B.M. 2004. Anticipatory activity and stereotypical behaviour in American mink (Mustela vison) in three housing systems differing in the amount of enrichments. Applied Animal Behaviour Science. 89: 145-161.

Warburton, H. \& Mason, G. 2003. Is out of sight out of mind? The effects of resource cues on motivation in mink, Mustela vison. Animal Behaviour 65: 755-762.

\title{
SELOSTUS
}

\section{Uima-altaat tarhatuilla minkeillä: yksilölliset erot uimakäyttäytymisessä ja vaikutukset hyvinvointiin}

\author{
Jaakko Mononen, Maarit Mohaibes, Sakari Savolainen ja Leena Ahola \\ Kuopion yliopisto
}

Tutkimme turkistiloilla kasvatettavien minkkien (Mustela vison) uimakäyttäytymistä ja sen mittaamista, uimakäyttäytymisessä esiintyvää yksilöllistä vaihtelua sekä uimismahdollisuuden vaikutusta stereotyyppiseen käyttäytymiseen kolmessa erillisessä kokeessa. Minkit kasvatettiin kaikissa kokeissa yksin kotihäkeissään, joista niillä oli pääsy toiseen häkkiin, jossa oli 20,5 litran uima-allas. Kahdessa lyhytkestoisessa (10 vuorokautta) kokeessa tutkittiin yksilöllistä vaihtelua uimisen määrässä sekä nuorilla että aikuisilla naarasminkeillä. Yhdessä pitkäkestoisessa (4 kuukautta) kokeessa verrattiin käyttäytymistä nuorilla naarasminkeillä, joilla ei ollut ja joilla oli käytettävissään uima-allas. Käyttäytymisen analysoinnit tehtiin 24 tunnin videonauhoituksista, joita tehtiin lyhytkestoisissa kokeissa kaksi tai kolme kertaa ja pitkäkestoisessa kokeessa neljä kertaa. Yksilöiden väliset erot uimakäyttäytymisessä olivat suuria, mutta yksilöiden uimakäyttäytyminen ei kuitenkaan vaihdellut paljoa eri mittauskertojen välillä, ja minkkien uimamotivaatiota voidaankin siten mitata luotettavasti myös lyhytkestoisissa kokeissa (etenkin nuorilla eläimillä). Minkkien turkin mukana uima-altaasta poistuneen veden määrä oli melko luotettava uimisen määrän mittari. Samoin käyttäytymisseurannoissa kymmenen minuutin tarkkailuväli riitti melko luotettavan kuvan saamiseen vuorokautisesta kokonaisuintimäärästä. Pitkäkestoisessa kokeessa havaittiin, että uima-altaiden kanssa eläneillä minkeillä oli vähemmän stereotyyppistä käyttäytymistä kuin ilman uima-altaita eläneillä minkeillä. Tämä osoittaa, että uima-altaat saattavat vähentää yksin kasvatettujen nuorten minkkien turhautumista ja parantaa siten niiden hyvinvointia. 